\title{
COVID-19 DAN E-LEARNING: PERUBAHAN STRATEGI PEMBELAJARAN SAINS DAN LINGKUNGAN DI SMP
}

\author{
Ilmi Zajuli Ichsan ${ }^{1,2 *}$, Henita Rahmayanti ${ }^{1}$, Agung Purwanto ${ }^{1}$, \\ Diana Vivanti Sigit ${ }^{2}$, Edi Kurniawan ${ }^{3}$, Aryani Kadarwati Dewi ${ }^{4}$, Nina Wirdianti ${ }^{5}$, \\ Farah Muthi Hermawati ${ }^{6}$, Giry Marhento ${ }^{7}$
}

${ }^{1}$ Pendidikan Kependudukan dan Lingkungan Hidup, Universitas Negeri Jakarta, Indonesia

${ }^{2}$ Pendidikan Biologi, Universitas Negeri Jakarta, Indonesia

${ }^{3}$ Pendidikan Geografi, Universitas Negeri Semarang, Indonesia

${ }^{4}$ Guru Mata Pelajaran IPA, SMP Negeri 1 Tambun Selatan, Bekasi, Jawa Barat, Indonesia

${ }^{5}$ Guru Mata Pelajaran IPA, SMP Negeri 51 Bandung, Bandung, Jawa Barat, Indonesia

${ }^{6}$ Pendidikan Fisika, Universitas Negeri Jakarta, Indonesia

${ }^{7}$ Pendidikan Biologi, Universitas Indraprasta PGRI, Indonesia

*Email: ilmizajuli95@gmail.com/ilmi.zajuli@outlook.co.id

\section{*Corresponden Author}

\begin{abstract}
ABSTRAK
Corona Virus Diseases (COVID-19) sudah menjadi wabah di Indonesia, bahkan sudah menjadi pandemik global di tahun 2020. Berbagai dampak dari COVID-19 ini salah satunya terjadi perubahan pada dunia pendidikan. Salah satunya adalah perubahan dari pembelajaran konvensional menjadi pembelajaran dengan berbasis internet atau electronic learning (elearning). Tujuan penelitian ini adalah untuk mendeskripsikan keadaan e-learning pada pembelajaran sains dan lingkungan saat wabah COVID-19. Metode penelitian yang digunakan adalah dengan metode deskriptif dan teknik pengambilan data menggunakan survey melalui google form. Penelitian dilaksanakan selama Maret 2020 saat wabah COVID-19 mulai mewabah di wilayah Indonesia. Hasil dari penelitian ini menunjukan bahwa banyak kendala yang dihadapi siswa. Salah satu temuan menunjukkan bahwa Whatsapp menjadi media e-learning yang tertinggi (65.54\%). Terkait kendala terbesar adalah kuota internet yang habis $(27.03 \%)$. Kemudian siswa berpendapat bahwa video (35.14\%) merupakan jenis file yang tepat untuk dibagikan saat $e$ learning. Kemudian mayoritas siswa $(54.73 \%)$ berpendapat bahwa durasi yang paling efektif untuk e-learning adalah 2-3 jam/hari. Hasil penelitian ini menunjukan bahwa e-learning belum berjalan sempurna dan perlu ditingkatkan. Kesimpulan dari penelitian ini adalah bahwa kendala saat e-learning yang dilakukan perlu diatasi dan perlu dilakukan inovasi oleh guru berupa pengembangan bahan ajar, media pembelajaran dan juga lembar kerja siswa.
\end{abstract}

Kata Kunci: COVID-19; E-Learning; Pembelajaran Sains dan Lingkungan.

\section{ABSTRACT}

Corona Virus Diseases (COVID-19) has become a pandemic in Indonesia, and even has become a global pandemic in 2020. Various impacts of COVID-19 is one of them changes learning strategy. One of them is the change from conventional learning to internet-based learning or electronic learning (e-learning). The purpose of this study was to describe the e-learning in natural science and environmental learning during the COVID-19 outbreak. The research method used descriptive method and data collection techniques using a survey through Google Form. The study was conducted during March 2020 in Bekasi city and Bandung city, when the COVID-19 outbreak began in Indonesia. The results of this study indicate that there are many problem for elearning. Finding showed that Whatsapp was the highest e-learning media (65.54\%). Related to the biggest problem is about internet quota in cellular phone $(27.03 \%)$. Then students opinion about video (35.14\%) was the best type of file to be shared in e-learning. Then the majority of students $(54.73 \%)$ thought that the most effective duration for e-learning was $2-3$ hours/day. The results of this study indicate that e-learning was not yet perfect and needs to be improved. The 
conclusion of this study was e-learning need to be improved and need innovation for developing teaching materials, learning media, and students worksheet.

Keywords: COVID-19; E-Learning; Science And Environmental Learning.

Copyright (c) 2020 Ichsan et al This is an open access article under the CC-BY license

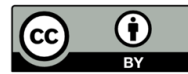

How to cite: Ichsan, I., Rahmayanti, H., Purwanto, A., Sigit, D., Kurniawan, E., Dewi, A., Wirdianti, N., Hermawati, F., \& Marhento, G. (2020). Covid-19 dan E-Learning: Perubahan Strategi Pembelajaran Sains dan Lingkungan di SMP. JINoP (Jurnal Inovasi Pembelajaran), 6(1). doi: https://doi.org/10.22219/jinop.v6i1.11791

\section{PENDAHULUAN}

Wabah Corona Viruses Diseases (COVID-19) merupakan sebuah pandemik global yang menyerang banyak negara di dunia pada tahun 2020 (Ahorsu et al., 2020; Bandyopadhyay, 2020; Pan, 2020; Salzberger et al., 2020). Wabah ini terjadi dikarenakan infeksi virus corona jenis baru yang diawali di Negara China, tepatnya di Wuhan (Tian et al., 2020; Zhou et al., 2020). Saat ini COVID-19 sudah menyebar ke berbagai wilayah, termasuk berbagai kota di wilayah Indonesia. Adanya COVID-19 ini mengakibatkan berbagai situasi ekonomi dan sosial terganggu. Contohnya aktivitas di pusat-pusat perekonomian menjadi sepi pengunjung dikarenakan kebijakan pemerintah Indonesia yang berisi himbauan kepada masyarakat untuk melakukan Physical Distancing (menjaga jarak antar individu). Hal ini mengakibatkan semua kegiatan menjadi berubah, sehingga beberapa instansi meliburkan kegiatannya. Dampak yang ditimbulkan adalah semua pekerjaan dilakukan secara dalam jaringan (online) dari rumah masing-masing atau disebut Work From Home (WFH), termasuk dalam kaitannya dengan kegiatan belajar dan mengajar di sekolah.

Adanya wabah COVID-19 ini mengakibatkan kegiatan belajar di beberapa kota besar seperti Jakarta, Bekasi, Tangerang, Depok, Bogor, Bandung dan kota lainnya menjadi terganggu. Siswa akhirnya tidak bisa belajar di sekolah karena semua sekolah ditutup mulai dari jenjang sekolah dasar, menengah, hingga perguruan tinggi. Kegiatan belajar pun berubah menjadi pembelajaran berbasis online atau disebut electronic learning (e-learning). Strategi pembelajaran e-learning ini dilakukan dengan berbagai cara mulai dari menggunakan website, media sosial, hingga teleconference (Alhawiti \& Abdelhamid, 2017; Elleithy \& Sobh, 2015; Golitsyna, 2017). Perkembangan e-learning dalam pembelajaran juga sudah banyak dikembangkan sebelumnya. Sebagai sebuah strategi pembelajaran yang relatif baru, e-learning harus terus dikembangkan lebih lanjut.

Penelitian terdahulu sudah banyak dilakukan pengembangan e-learning. Pembelajaran dengan e-learning banyak menggunakan media sosial yang sudah ada (Blaschke, 2014; Boholano, 2017; Reyna et al., 2018). Beberapa penelitian menunjukan bahwa belajar dengan media sosial ternyata cukup ampuh untuk meningkatkan kemampuan siswa (Brown, 2017; Caird \& Hallett, 2019; Runhaar et al., 2019; Sahronih et al., 2019; Sutter \& Smith, 2017). Selain itu, siswa juga dapat beradaptasi dengan kemajuan teknologi. Selain penggunaan media sosial, banyak penelitian menunjukan penggunaan website dan multimedia lain ternyata masih diminati oleh siswa (Fatih, 2016; Nugraini et al., 2013). Hal ini menandakan penggunaan teknologi dalam pembelajaran 
masih dimungkinkan. Khususnya dalam pembelajaran sains (Ilmu Pengetahuan Alam) dan lingkungan, penggunaan e-learning sangat dimungkinkan.

Permasalahan yang muncul adalah banyak siswa yang belum terbiasa menggunakan e-learning. Adanya wabah COVID-19 ini membuat siswa harus bisa belajar menggunakan e-learning. Hal itu menyebabkan siswa yang belum terbiasa harus beradaptasi terlebih dahulu, khususnya siswa pada jenjang sekolah menengah pertama (SMP). Siswa harus dapat melakukan adaptasi dalam pembelajaran sains dan lingkungan dengan e-learning. Berdasarkan uraian tersebut, maka perlu dilakukan sebuah deskripsi untuk mengetahui respon siswa dalam menggunakan e-learning pada saat wabah COVID-19 secara umum, khususnya pada saat mempelajari sains dan lingkungan. Tujuan penelitian ini adalah untuk mendeskripsikan keadaan $e$-learning pada pembelajaran sains (Ilmu Pengetahuan Alam/IPA) dan lingkungan saat wabah COVID-19, sebagai sebuah novelty dalam penelitian pendidikan disaat COVID-19.

\section{METODE}

Penelitian dilaksanakan pada bulan Maret 2020 bertepatan dengan mewabahnya Corona Virus Diseases (COVID-19) di wilayah Indonesia. Penelitian ini dilaksanakan dengan metode deskriptif menggunakan teknik pengambilan data yaitu survey. Sampel yang dilibatkan dalam penelitian ini adalah siswa Sekolah Menengah Pertama (SMP) di wilayah Bekasi dan Bandung. Sampel dipilih secara acak dan terpilih 148 siswa SMP sebagai sampel yang sudah menggunakan strategi pembelajaran berupa e-learning. Instrumen yang dibuat adalah berupa angket yang berisi pertanyaan mengenai berbagai pendapat siswa mengenai e-learning akibat adanya wabah COVID-19. Instrumen disebar melalui media sosial. Instrumen yang dibuat dalam bentuk angket yang dapat diisi siswa pada Google form. Instrumen terdiri dari 3 bagian yaitu (1) Respon siswa terkait penggunaan e-learning (2) Respon siswa terkait efektivitas penggunaan e-learning (3) detail penggunaan e-learning saat wabah COVID-19 dalam pembelajaran sains.

Instrumen pertama terkait dengan respon siswa dalam penggunaan e-learning memiliki opsi pilihan jawaban sangat setuju, setuju, ragu-ragu, tidak setuju, dan sangat tidak setuju. Seluruh butir instrument merupakan pernyataan positif. Adapun instrumen kedua merupakan sebuah instrumen berupa respon siswa terkait efektivitas penggunaan e-learning. Opsi jawaban yang disediakan adalah mulai dari sangat sangat efektif, efektif, cukup efektif, tidak efektif, dan sangat tidak efektif. Sementara itu, untuk instrumen ketiga merupakan pertanyaan dengan jawaban yang beraneka ragam terkait dengan detail menggunakan e-learning. Analisis data yang digunakan dalam penelitian ini adalah dengan cara mendeskripsikan berbagai hasil penelitian tersebut dalam bentuk persentase. Hal ini untuk melihat persentase dari penggunaan e-learning ini dalam pembelajaran sains dan lingkungan. Hasil analisis data terkait dengan media pembelajaran dan bahan ajar yang digunakan dalam e-learning ini disajikan dalam bentuk tabel dan grafik. Tujuannya untuk memudahkan melihat persentase yang terbesar dan terkecil dari jawaban siswa.

\section{HASIL DAN PEMBAHASAN}

Hasil dari penelitian ini menunjukkan bahwa secara umum siswa setuju dengan digunakannya e-learning saat pandemik COVID-19 dalam pembelajaran sains dan lingkungan. Namun ada beberapa catatan yang menarik yaitu terkait dengan kemudahan dalam memahami topik bahasan atau materi pembelajaran yang disampaikan melalui $e$ - 
learning. Hasil penelitian menunjukan bahwa sebanyak 40.54\% siswa menjawab raguragu. Sementara itu sebanyak $10.81 \%$ siswa menjawab tidak setuju. Hal ini menunjukan bahwa sebagian besar siswa masih merasa topik yang diajarkan melalui e-learning tidak mudah dipahami. Selengkapnya data lebih detail dapat dilihat pada Tabel 1.

Tabel 1. Persentase respon siswa terkait e-learning saat wabah COVID-19

\begin{tabular}{|c|c|c|c|c|c|c|}
\hline No & Pernyataan & $\begin{array}{l}\text { Sangat } \\
\text { Setuju }\end{array}$ & Setuju & $\begin{array}{l}\text { Ragu- } \\
\text { ragu }\end{array}$ & $\begin{array}{l}\text { Tidak } \\
\text { Setuju }\end{array}$ & $\begin{array}{l}\text { Sangat } \\
\text { Tidak } \\
\text { Setuju }\end{array}$ \\
\hline 1 & 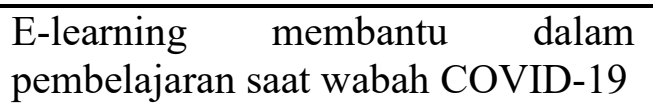 & 21.62 & 58.78 & 14.19 & 5.41 & 0.00 \\
\hline 2 & $\begin{array}{l}\text { E-learning dapat membuat saya } \\
\text { semakin mandiri dalam belajar }\end{array}$ & 10.14 & 50.00 & 31.08 & 6.76 & 2.03 \\
\hline 3 & $\begin{array}{l}\text { Materi yang dibagikan melalui media } \\
\text { saat E-learning dapat saya pelajari } \\
\text { sendiri dan saya mudah } \\
\text { memahaminya }\end{array}$ & 6.08 & 40.54 & 40.54 & 10.81 & 2.03 \\
\hline 4 & $\begin{array}{l}\text { Pada saat ada E-learning akibat } \\
\text { wabah COVID-19, terjadi diskusi } \\
\text { tanya jawab di media E-learning } \\
\text { antara sesama teman dengan guru }\end{array}$ & 17.57 & 64.19 & 14.86 & 2.70 & 0.68 \\
\hline 5 & $\begin{array}{l}\text { Saat wabah COVID-19, sebagian } \\
\text { besar siswa akan aktif } \\
\text { berkomentar/menanggapi saat terjadi } \\
\text { sesi diskusi di media E-learning pada } \\
\text { saat ada tugas pelajaran }\end{array}$ & 14.86 & 70.27 & 11.49 & 3.38 & 0.00 \\
\hline
\end{tabular}

Setelah dilakukan pengukuran respon siswa terhadap adanya e-learning, data berikutnya disajikan dalam Tabel 2 adalah terkait dengan respon siswa terhadap efektivitas dari e-learning. Hasilnya menunjukan bahwa hanya $7.43 \%$ siswa yang berpendapat bahwa e-learning tidak efektif dan $1.35 \%$ siswa berpendapat bahwa $e$ learning sangat tidak efektif digunakan saat wabah COVID-19. Haisl lebih jelas dapat dilihat pada Tabel 2 .

Tabel 2. Persentase respon siswa efektivitas e-learning saat COVID-19

\begin{tabular}{lllllll}
\hline No & \multicolumn{1}{c}{ Pernyataan } & $\begin{array}{c}\text { Sangat } \\
\text { efektif }\end{array}$ & Efektif & $\begin{array}{c}\text { Cukup } \\
\text { efektif }\end{array}$ & $\begin{array}{c}\text { Tidak } \\
\text { efektif }\end{array}$ & $\begin{array}{c}\text { Sangat } \\
\text { tidak } \\
\text { efektif }\end{array}$ \\
\hline $1 \quad \begin{array}{l}\text { Menurut anda, secara umum apakah } \\
\text { pembelajaran dengan E-learning } \\
\text { efektif digunakan dalam pembelajaran } \\
\text { saat wabah COVID-19? }\end{array}$ & 10.81 & 40.54 & 39.86 & 7.43 & 1.35 \\
2 & & & & & \\
$\begin{array}{l}\text { Menurut anda, penilaian/ujian/tes } \\
\text { melalui E-learning apakah efektif } \\
\text { dilakukan saat wabah COVID-19? }\end{array}$ & 9.46 & 26.35 & 38.51 & 20.95 & 4.73 \\
\hline
\end{tabular}

Ilmi Zajuli Ichsan, Henita Rahmayanti, Agung Purwanto, Diana Vivanti Sigit, Edi Kurniawan, Aryani Kadarwati Dewi, Nina Wirdianti, Farah Muthi Hermawati, Giry Marhento, Covid-19 dan E-Learning: Perubahan Strategi Pembelajaran Sains dan Lingkungan di SMP 
Berikutnya adalah hasil penelitian terkait dengan jenis media yang paling sesuai/cocok yang digunakan dalam e-learning, dapat dilihat pada Gambar 1. Hasilnya menunjukan bahwa penggunaan Whatsapp menjadi yang tertinggi (65.54\%). Semantara penggunaan website menjadi urutan terbanyak kedua setelah whatsapp. Hasil penelitian ini menunjukan bahwa siswa SMP dan guru sains mayoritas menggunakan whatsapp sebagai media e-learning saat wabah COVID-19.

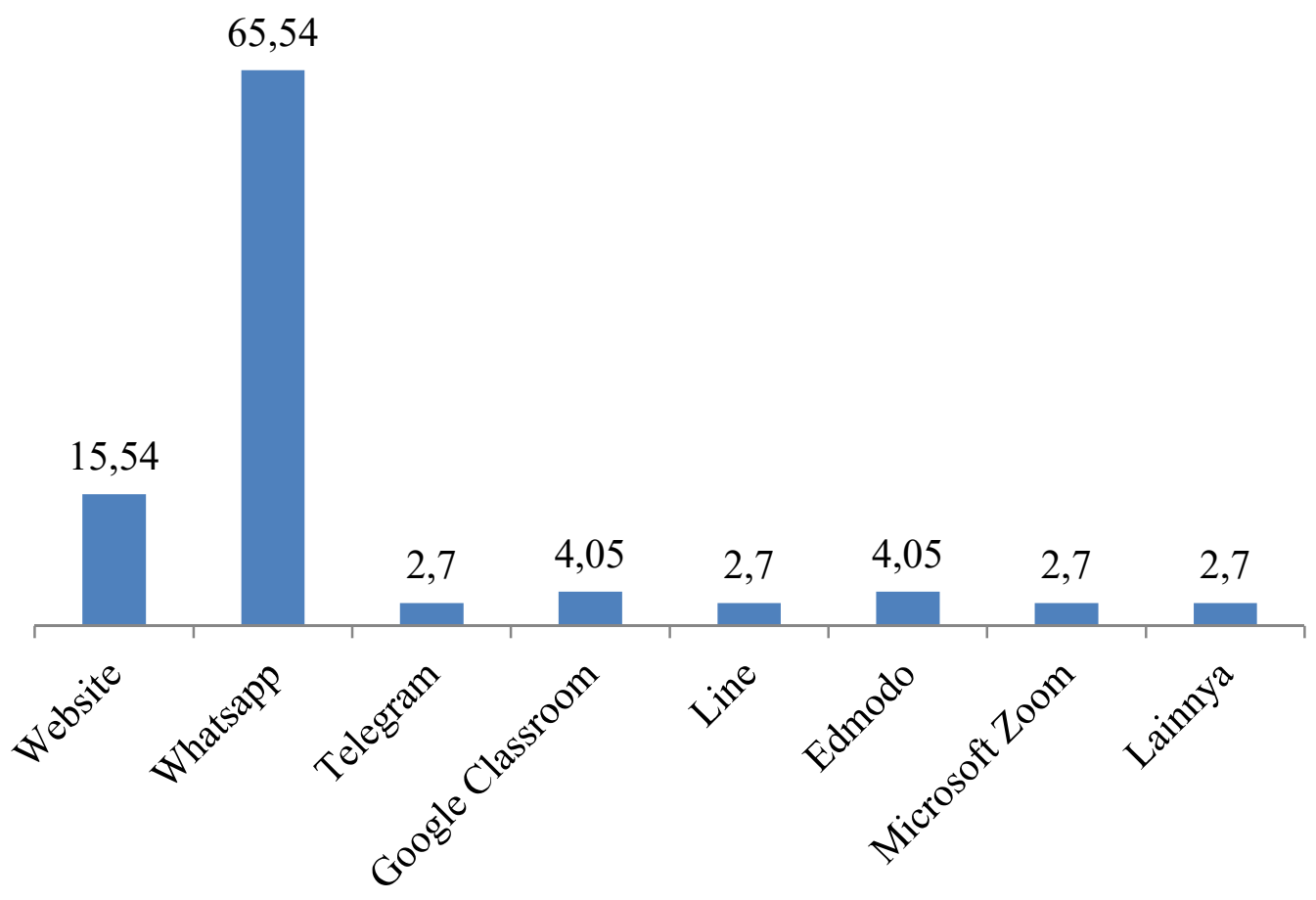

Gambar 1. Persentase media e-learning yang paling sesuai menurut siswa

Berikutnya adalah terkait jenis file yang dirasa paling sesuai untuk dibagikan (sharing) di media e-learning. Pilihan jawabannya tersedia mulai dari powerpoint, gambar (jpg/png), video, dokumen word, dan dokumen pdf. Hasil penelitian ini menunjukkan bahwa siswa berpendapat bahwa video $(35.14 \%)$ sebagai jenis file yang paling cocok untuk dibagikan saat proses e-learning. Hasil penelitian selengkapnya dapat dilihat pada Gambar 2.

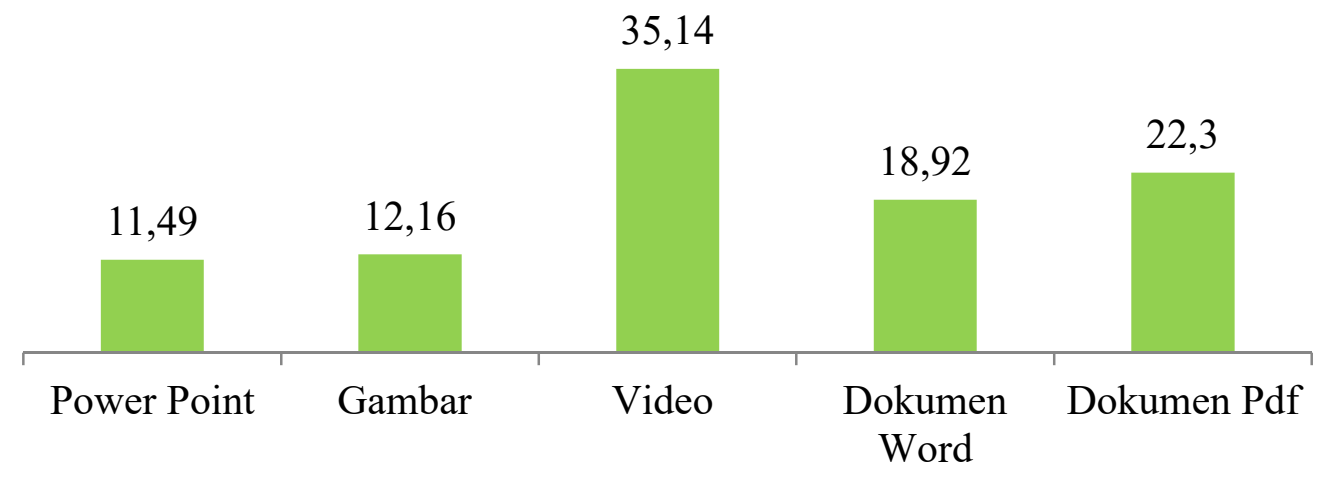

Gambar 2. Persentase Jenis File yang dibagikan menurut siswa 
Selain penggunaan media dan jenis file, siswa juga dimintai pendapat mengenai durasi efektif dalam penggunaan e-learning. Hasil dari penelitian ini menunjukkan bahwa mayoritas (54.73\%) berpendapat bahwa durasi yang paling efektif adalah 2-3 jam dalam satu hari. Sedangkan persentase terbesar kedua (26.35\%) berpendapat bahwa durasi 4-6 jam dalam satu hari adalah yang efektif. Hasil lebih jelas dapat dilihat pada Gambar 3.

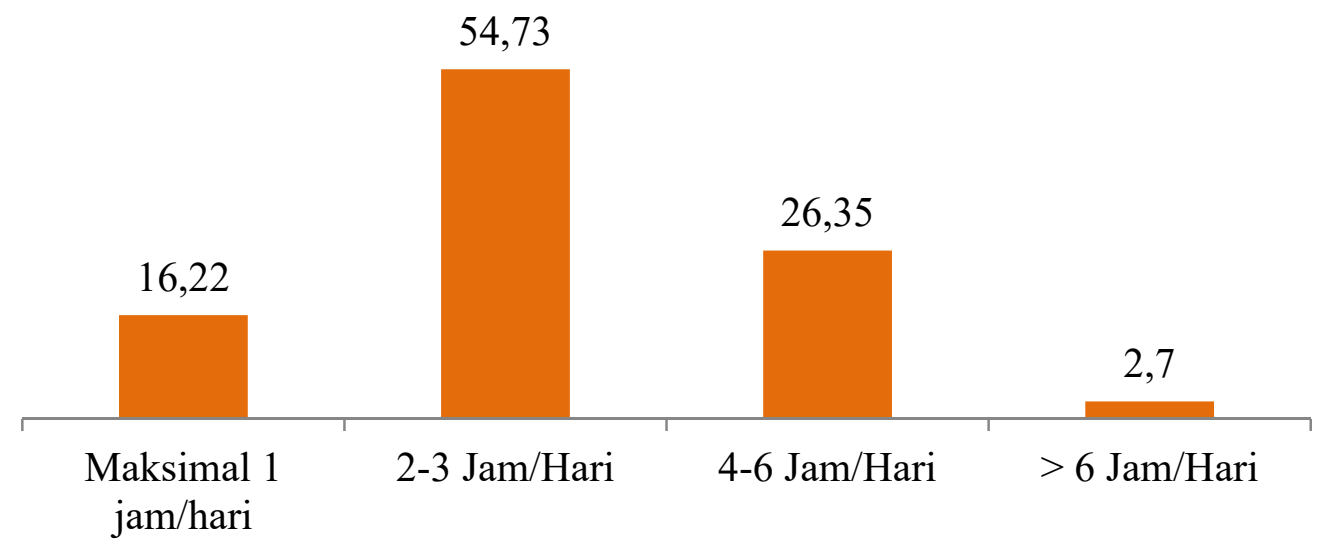

Gambar 3. Persentase lama durasi e-learning yang efektif menurut siswa

Sementara itu hasil menunjukan bahwa kendala yang dialami siswa dengan persentase terbesar adalah terkait kuota internet yang habis (27.03\%). Sementara urutan kedua adalah terkait dengan sinyal seluler yang terganggu $(22.97 \%)$, serta urutan ketiga yaitu wifi terganggu (21.62\%). Hasil lengkap dari penelitian ini dapat dilihat pada Gambar 4.

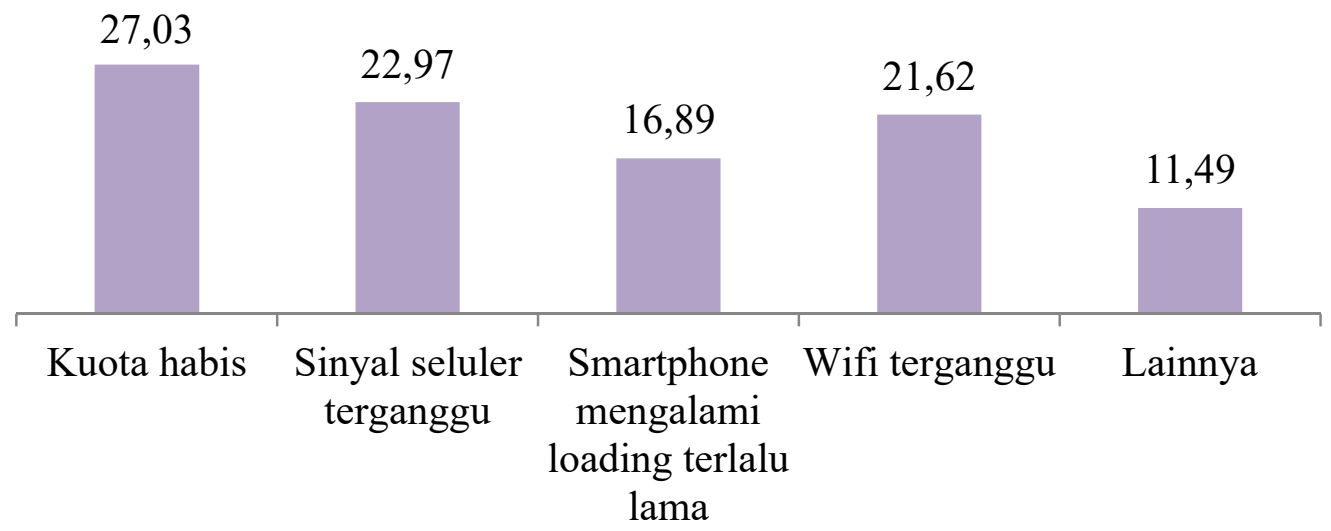

Gambar 4. Persentase Kendala yang dialami siswa dalam e-learning

Terakhir, terkait dengan persentase jenis koneksi yang digunakan oleh siswa dalam e-learning di rumah apda Gambar 5. Mayoritas siswa masih menggunakan paket data seluler $(56.76 \%)$. Hasil ini menunjukan bahwa penggunaan data selular juga akan mengalami kenaikan dengan adanya e-learning saat wabah COVID-19. Sementara itu 
untuk siswa yang menggunakan koneksi wifi di rumah atau memiliki koneksi wifi pribadi dirumah belum terlalu dominan (43.24\%).

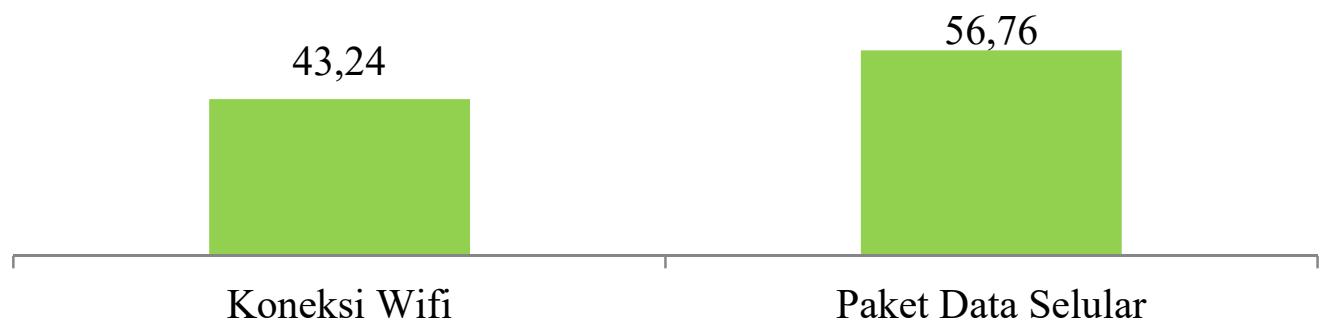

Gambar 5. Persentase Jenis koneksi siswa di rumah dalam e-learning

Berdasarkan hasil penelitian ini dapat diperoleh hasil bahwa penggunaan strategi pembelajaran menggunakan e-learning dalam pembelajaran sains dan lingkungan saat wabah COVID-19 belum berjalan optimal. Inovasi telah dilakukan oleh guru dengan cara mengubah kelas tatap muka menjadi bentuk e-learning. Selain itu, guru sudah melakukan inovasi dalam hal media pembelajaran dan bahan ajar yang bersifat digital. Inovasi yang dilakukan guru membantu dalam pelaksanaan e-learning di dunia pendidikan yang akan membantu pembelajaran disaat pandemik COVID-19, khususnya pada jenjang sekolah menengah pertama. Inovasi lain yang dapat dilakukan guru adalah dengan mengembangkan alat evaluasi yang bersifat online. Walaupun begitu, masih terdapat siswa yang mengalami berbagai kendala dalam pembelajaran. Berbagai persiapan seharusnya bisa dilakukan dengan lebih matang. Mulai dari persiapan sarana dan prasarana hingga kesiapan fisik dan mental dari siswa. Hal itu dikarenakan selain memerlukan alat berupa teknologi dan internet, perlu juga tubuh yang sehat saat mengikuti e-learning dengan durasi yang cukup lama. Strategi e-learning ini akan efektif jika seluruh sarana dan kesiapan siswa sudah terpenuhi semuanya, sehingga siswa akan bisa lebih aktif dalam belajar (Acharya, 2019; Hamouda \& Tarlochan, 2015; Hidayati \& Wuryandari, 2012; Kew et al., 2018; Mirabolghasemi et al., 2019; So et al., 2019; Uzun, 2012).

Berbagai kekurangan dan kendala yang terjadi selama penggunaan strategi pembelajaran menggunakan e-learning memang membuat pembelajaran sains dan lingkungan menjadi sedikit terhambat. Meskipun begitu, e-learning ini merupakan salah satu solusi agar pembelajaran bisa terus berlangsung saat ada wabah COVID-19. Peran serta siswa dalam e-learning yang paling menentukan kesuksesan dari dilaksanakannya e-learning ini. Siswa yang aktif berpartisipasi dan memberikan komentar saat pelajaran berlansung dengan e-learning, akan membuat pemahaman siswa tersebut semakin memahami ilmu yang dipelajari (Al-araibi et al., 2019; Back et al., 2015; Ichsan, Sigit, et al., 2020; Kew et al., 2018; Mhouti et al., 2017; Nwagwu, 2020; Pham et al., 2019). Sebagai sebuah strategi pembelajaran, e-learning merupakan pilihan yang paling ideal saat terjadi wabah COVID-19. Hal itu dikarenakan pertemuan dengan tatap muka sangat sulit dilakukan dan tidak memungkinkan karena perlunya physical distancing (menjaga jarak antar individu) untuk menghindari tersebarnya COVID-19.

Pembelajaran sains dan lingkungan menggunakan strategi pembelajaran e-learning ini bukan suatu hal yang benar-benar baru. Sudah banyak sebelumnya diperkenalkan berbagai perangkat teknologi dan berbagai program software yang dibuat untuk menunjang e-learning. Permasalahan yang muncul adalah wabah COVID-19 ini begitu 
cepat merubah pola yang sudah ada. Pola sebelumnya adalah pembelajaran sains dan lingkungan di jenjang SMP secara umum masih didominasi dengan tatap muka di kelas. Setelah wabah COVID-19 ini terjadi maka persiapan sarana dan sistem yang tersedia belum disiapkan dengan matang sebelumnya. Hal itu mengakibatkan munculnya berbagai kendala dari pelaksanaan e-learning ini. Sebaiknya sebelum dilakukan e-learning, maka kesiapan sarana dan pra-sarana harus dilakukan dengan agar semua kegiatan e-learning berjalan dengan baik (Rahmayanti, Ichsan, Oktaviani, et al., 2020; So et al., 2019; Teo et al., 2018).

Sistem e-learning yang baik seharusnya didesain oleh pihak terkait yaitu dinas pendidikan dan sekolah. Seharusnya setiap sekolah memiliki sistem e-learning masingmasing yang bisa diakses kapan saja, bukan hanya saat wabah COVID-19. Sehingga apapun yang terjadi kesiapan infrastrutur dari e-learning ini sudah terpenuhi untuk sewaktu-waktu digunakan. Hal ini dapat meminimalisir berbagai kendala yang terjadi saat terjadi wabah seperti COVID-19 ini. Problem lain yang muncul dari dilaksanakannya e-learning ini adalah terkadang banyak tugas yang diberikan oleh guru kepada siswa. Hal ini sebenarnya bisa diantisipasi dengan cara membatasi jumlah tugas yang diberikan setiap harinya. Kepala sekolah memiliki wewenang untuk memberikan teguran kepada guru yang memberikan tugas terlalu banyak. Selain itu, e-learning juga bisa diganti dilakukan inovasi dengan berbagai permainan dan media pembelajaran (Ichsan, 2019; Inchamnan, 2016; Lay \& Osman, 2018; Lee, 2016; Rahmayanti, Oktaviani, et al., 2020; Sandberg \& Ohman, 2011).

Saat melaksanakan e-learning dalam pembelajaran sains dan lingkungan seperti saat wabah COVID-19, sebaiknya siswa diajak untuk menjelajahi berbagai video terkait topik yang dipelajari. Sesuai dengan hasil temuan dari penelitian ini bahwa video merupakan salah satu jenis media yang paling diminati oleh siswa. Guru tidak harus membuat sendiri video pembelajaran, melainkan bisa mengambil dari berbagai sumber yang valid. Media ini akan sangat membantu siswa dalam memahami berbagai materi, ketimbang harus membaca teks yang berisi banyak tulisan. Kecanggihan teknologi multimedia sangat membantu mendukung pembelajaran sains dan lingkungan dengan $e$ learning (Gündüz et al., 2016; Ichsan, Rahmayanti, et al., 2020; Rahmayanti, Ichsan, Azwar, et al., 2020; Said \& Syarif, 2016; Tyabaev et al., 2015). Pembelajaran menggunakan e-learning untuk kedepannya harus terus dilakukan pembenahan lebih lanjut untuk bisa memperbaiki kualitas pendidikan saat ini. Adanya pandemik COVID19 seharusnya menjadi momentum untuk melakukan pembenahan pendidikan, terutama agar siswa mulai terbiasa menggunakan media pembelajaran berbasis teknologi.

\section{SIMPULAN}

Berdasarkan hasil penelitian yang telah dilakukan menunjukan bahwa keadaan pelaksanaan e-learning dalam pembelajaran sains dan lingkungan di saat COVID-19 sudah berjalan dengan baik. Adapun kendala pelaksanaan e-learning saat wabah COVID19 masih perlu diatasi. Kendala seperti koneksi internet yang tidak lancar dan materi yang dibagikan guru terasa sulit dipahami siswa, serta kendala lainnya. Kendala ini bisa diatasi seandainya persiapan yang dilakukan lebih matang. Selain itu guru juga bisa melakukan sebuah inovasi dengan memberikan konten-konten yang menarik terkait topik pembelajaran sains dan lingkungan yang dipelajari. Rekomendasi dari penelitian ini adalah dapat dilakukan sebuah penelitian lanjutan mengenai pengetahuan siswa mengenai

Ilmi Zajuli Ichsan, Henita Rahmayanti, Agung Purwanto, Diana Vivanti Sigit, Edi Kurniawan, Aryani Kadarwati Dewi, Nina Wirdianti, Farah Muthi Hermawati, Giry Marhento, Covid-19 dan E-Learning: Perubahan Strategi Pembelajaran Sains dan Lingkungan di SMP 
COVID-19 dan upaya pencegahan yang telah dilakukan terkait COVID-19 dalam kaitanya dalam pembelajaran sains dan lingkungan.

\section{DAFTAR PUSTAKA}

Acharya, S. (2019). Beyond Learning Outcomes: Impact of Organizational Flexibility on Strategic Performance Measures of Commercial E-Learning Providers. Global Journal of Flexible Systems Management, 20(1), 31-41. https://doi.org/10.1007/s40171-018-0199-3

Ahorsu, D. K., Lin, C.-Y., Imani, V., Saffari, M., Griffiths, M. D., \& Pakpour, A. H. (2020). The Fear of COVID-19 Scale: Development and Initial Validation. International Journal of Mental Health and Addiction, 1-9. https://doi.org/10.1007/s11469-020-00270-8

Al-araibi, A. A. M., Mahrin, M. N. bin, \& Yusoff, R. C. M. (2019). Technological aspect factors of E-learning readiness in higher education institutions: Delphi technique. Education and Information Technologies, 24(1), 567-590. https://doi.org/10.1007/s10639-018-9780-9

Alhawiti, M. M., \& Abdelhamid, Y. (2017). A Personalized e-Learning Framework. Journal of Education and E-Learning Research, 4(1), 15-21. https://doi.org/10.20448/journal.509.2017.41.15.21

Back, D. A., Behringer, F., Harms, T., Plener, J., Sostmann, K., \& Peters, H. (2015). Survey of e-learning implementation and faculty support strategies in a cluster of mid-European medical schools. BMC Medical Education, 15(1), 1-9. https://doi.org/10.1186/s12909-015-0420-4

Bandyopadhyay, S. (2020). Coronavirus Disease 2019 (COVID-19): we shall overcome. Clean Technologies and Environmental Policy. https://doi.org/10.1007/s10098-02001843-w

Blaschke, L. M. (2014). Using Social Media to Engage and Develop The Online Learner in Self-Determined Learning. Research in Learning Technology, 22(1), 1-23. https://doi.org/10.3402/rlt.v22.21635

Boholano, H. B. (2017). Smart Social Networking: 21st Century Teaching And Learning Skills. Research in Pedagogy, 7(1), 21-29. https://doi.org/10.17810/2015.45

Brown, N. (2017). Updating assessment styles: Website development rather than report writing for project based learning courses. Advances in Engineering Education, 6(2), $1-16$.

Caird, S. P., \& Hallett, S. H. (2019). Towards evaluation design for smart city development. Journal of Urban Design, 24(2), 188-209. https://doi.org/10.1080/13574809.2018.1469402

Elleithy, K., \& Sobh, T. (2015). New Trends in Networking, Computing, E-learning, Systems Sciences, and Engineering. In K. Elleithy \& T. Sobh (Eds.), Lecture Notes in Electrical Engineering (Vol. 312). Springer International Publishing. https://doi.org/10.1007/978-3-319-06764-3

Fatih, M. T. uuml rker. (2016). Design process for online websites created for teaching Turkish as a foreign language in web based environments. Educational Research and Reviews, 11(8), 642-655. https://doi.org/10.5897/ERR2015.2511

Golitsyna, I. (2017). Educational Process in Electronic Information-educational Environment. Procedia - Social and Behavioral Sciences, 237, 939-944. 
https://doi.org/10.1016/j.sbspro.2017.02.132

Gündüz, A. Y., Alemdağ, E., Yaşar, S., \& Erdem, M. (2016). Design of a problem-based online learning environment and evaluation of its effectiveness. The Turkish Online Journal of Educational Technology, 15(3), 49-57. https://doi.org/10.1017/CBO9781107415324.004

Hamouda, A. M. S., \& Tarlochan, F. (2015). Engaging engineering students in active learning and critical thinking through class debates. Procedia - Social and Behavioral Sciences, 191, 990-995. https://doi.org/10.1016/j.sbspro.2015.04.379

Hidayati, N., \& Wuryandari, A. I. (2012). Media Design for Learning Indonesian in Junior High School Level. Procedia - Social and Behavioral Sciences, 67, 490-499. https://doi.org/10.1016/j.sbspro.2012.11.354

Ichsan, I. Z. (2019). ILMIZI: Innovation Learning Model for Natural Science and Environmental Learning based on HOTS. International Journal for Educational and Vocational Studies, 1(6), 578-584. https://doi.org/10.29103/ijevs.v1i6.1640

Ichsan, I. Z., Rahmayanti, H., Purwanto, A., Sigit, D. V., \& Rahman, M. M. (2020). PEBCOVID-19: Analysis of Students Behavior and ILMIZI Model in Environmental Learning. Jurnal Iqra': Kajian Ilmu Pendidikan, 5(1), 1-11. https://doi.org/10.25217/ji.v5i1.901

Ichsan, I. Z., Sigit, D. V., Rahmayanti, H., Purwanto, A., Rosyid, A., Suwandi, T., Ali, A., \& Hermawati, F. M. (2020). Implementasi model pembelajaran ILMIZI dan peningkatan HOTS siswa SD berdasarkan gender pada pembelajaran lingkungan. JIPVA (Jurnal Pendidikan IPA Veteran), 4(1), 11-24. https://doi.org/10.31331/jipva.v4i1.1076

Inchamnan, W. (2016). An Analysis of Creative Process Learning in Computer Game Activities Through Player Experiences. IAFOR Journal of Education, 4(2), 119139.

Kew, S. N., Petsangsri, S., Ratanaolarn, T., \& Tasir, Z. (2018). Examining the motivation level of students in e-learning in higher education institution in Thailand: A case study. Education and Information Technologies, 23(6), 2947-2967. https://doi.org/10.1007/s10639-018-9753-z

Lay, A. N., \& Osman, K. (2018). Developing 21 st Century Chemistry Learning through Designing Digital Games. Journal of Education in Science, Environment and Health, 4(1), 81-92. https://doi.org/10.21891/jeseh.387499

Lee, A. Y. L. (2016). Media education in the School 2.0 era: Teaching media literacy through laptop computers and iPads. Global Media and China. https://doi.org/10.1177/2059436416667129

Mhouti, A. El, Nasseh, A., Erradi, M., \& Vasquèz, J. M. (2017). Enhancing collaborative learning in Web 2.0-based e-learning systems: A design framework for building collaborative e-learning contents. Education and Information Technologies, 22(5), 2351-2364. https://doi.org/10.1007/s10639-016-9545-2

Mirabolghasemi, M., Choshaly, S. H., \& Iahad, N. A. (2019). Using the HOT-fit model to predict the determinants of E-learning readiness in higher education: a developing Country's perspective. Education and Information Technologies, 24(6), 3555-3576. https://doi.org/10.1007/s10639-019-09945-9

Nugraini, S. H., Choo, K. A., Hin, H. S., \& Hoon, T. S. (2013). Impact of E-Av Biology Website for Learning About Renewable Energy. TOJET: The Turkish Online Journal of Educational Technology, 12(2), 376-386.

Ilmi Zajuli Ichsan, Henita Rahmayanti, Agung Purwanto, Diana Vivanti Sigit, Edi Kurniawan, Aryani Kadarwati Dewi, Nina Wirdianti, Farah Muthi Hermawati, Giry Marhento, Covid-19 dan E-Learning: Perubahan Strategi Pembelajaran Sains dan Lingkungan di SMP 
Nwagwu, W. E. (2020). E-learning readiness of universities in Nigeria- what are the opinions of the academic staff of Nigeria's premier university? Education and Information Technologies, 25(2), 1343-1370. https://doi.org/10.1007/s10639-01910026-0

Pan, X. B. (2020). Application of personal-oriented digital technology in preventing transmission of COVID-19, China. Irish Journal of Medical Science, 1-2. https://doi.org/10.1007/s11845-020-02215-5

Pham, L., Limbu, Y. B., Bui, T. K., Nguyen, H. T., \& Pham, H. T. (2019). Does e-learning service quality influence e-learning student satisfaction and loyalty? Evidence from Vietnam. International Journal of Educational Technology in Higher Education, 16(7), 1-26. https://doi.org/10.1186/s41239-019-0136-3

Rahmayanti, H., Ichsan, I. Z., Azwar, S. A., Kurniawan, E., Irawan, B., \& Titin, T. (2020). Indonesian Student Environmental Attitude of flood during COVID-19: DIFMOL Education Model in 21st Technology. International Journal of Advanced Science and Technology, 29(5), 6245-6253.

Rahmayanti, H., Ichsan, I. Z., Oktaviani, V., Syani, Y., Hadi, W., \& Marhento, G. (2020). Environmental Attitude for Smart City Technology: Need Assessment to Develop Smart Trash in Environmental Education. International Journal of Advanced Science and Technology, 29(3), 8374-8383.

Rahmayanti, H., Oktaviani, V., \& Syani, Y. (2020). Development of sorting waste game android based for early childhood in environmental education. Journal of Physics: Conference Series, 1434(1), 12029. https://doi.org/10.1088/17426596/1434/1/012029

Reyna, J., Hanham, J., \& Meier, P. (2018). The Internet explosion, digital media principles and implications to communicate effectively in the digital space. ELearning and Digital Media, 15(1), 36-52. https://doi.org/10.1177/2042753018754361

Runhaar, P., Wagenaar, K., Wesselink, R., \& Runhaar, H. (2019). Encouraging Students' Pro-environmental Behaviour: Examining the Interplay Between Student Characteristics and the Situational Strength of Schools. Journal of Education for Sustainable Development, 13(1), 45-66. https://doi.org/10.1177/0973408219840544

Sahronih, S., Purwanto, A., \& Sumantri, M. S. (2019). The effect of interactive learning media on students' science learning outcomes. ACM International Conference Proceeding Series, 20-24. https://doi.org/10.1145/3323771.3323797

Said, A., \& Syarif, E. (2016). The Development of Online Tutorial Program Design Using Problem-Based Learning in Open Distance Learning System. Journal of Education and Practice, 7(18), 222-229.

Salzberger, B., Glück, T., \& Ehrenstein, B. (2020). Successful containment of COVID19: the WHO-Report on the COVID-19 outbreak in China. Infection, 48, 151-153. https://doi.org/10.1007/s15010-020-01409-4

Sandberg, K. W., \& Ohman, G. (2011). Learning in innovation development. Procedia Social and Behavioral Sciences, 28, 379-383. https://doi.org/10.1016/j.sbspro.2011.11.072

So, W. W. M., Chen, Y., \& Wan, Z. H. (2019). Multimedia e-Learning and SelfRegulated Science Learning: a Study of Primary School Learners' Experiences and Perceptions. Journal of Science Education and Technology, 28(5), 508-522. 
https://doi.org/10.1007/s10956-019-09782-y

Sutter, D., \& Smith, D. J. (2017). Coordination in disaster: Nonprice learning and the allocation of resources after natural disasters. Review of Austrian Economics, 30(4), 469-492. https://doi.org/10.1007/s11138-016-0369-5

Teo, T. S. H., Kim, S. L., \& Jiang, L. (2018). E-Learning Implementation in South Korea: Integrating Effectiveness and Legitimacy Perspectives. Information Systems Frontiers. https://doi.org/10.1007/s10796-018-9874-3

Tian, S., Hu, N., Lou, J., Chen, K., Kang, X., Xiang, Z., Chen, H., Wang, D., Liu, N., Liu, D., Chen, G., Zhang, Y., Li, D., Li, J., Lian, H., Niu, S., Zhang, L., \& Zhang, J. (2020). Characteristics of COVID-19 infection in Beijing. Journal of Infection, 80(4), 401-406. https://doi.org/10.1016/j.jinf.2020.02.018

Tyabaev, A. E., Sedelnikova, S. F., \& Voytovich, A. V. (2015). Student-Centered Learning: The Experience of Teaching International Students in Russian Universities. Procedia - Social and Behavioral Sciences, 215(June), 84-89. https://doi.org/10.1016/j.sbspro.2015.11.578

Uzun, N. (2012). A Sample of Active Learning Application in Science Education: The Thema "Cell" with Educational Games. Procedia - Social and Behavioral Sciences, 46, 2932-2936. https://doi.org/10.1016/j.sbspro.2012.05.592

Zhou, G., Chen, S., \& Chen, Z. (2020). Back to the spring of Wuhan: facts and hope of COVID-19 outbreak. Frontiers of Medicine, 1-4. https://doi.org/10.1007/s11684020-0758-9 